\title{
The Shaping of the Nation in Nanon and 93
}

Alice AUDOIN

ccording to Richard Terdiman the $1789-1815$ revolutionary
rupture traumatized XIXth century French society, because it
dissociated the present from collective historical memory. In Terdiman's words, French people experienced a "'memory crisis': a sense that their past had somehow evaded memory, that recollection had ceased to integrate with consciousness. In this memory crisis the very coherence of time and of subjectivity seemed disarticulated" (3-4).

Indeed, the pre-revolutionary past, which French people of the nineteenth-century may have recalled, is no longer inscribed in historical continuity throughout the new century. The succession of various regimes illustrated the struggle of a people trying to make sense of the new historical dynamic arising after 1789. Eventually, we may affirm that there will be no going back to the past. On September 17, 1853, Edgar Quinet, after he finished reading the last volumes of La Révolution francaise by Michelet, wrote Michelet a letter in which he claims that "[v]ous avez tiré le rideau. Tout désir d'imitation devrait cesser pour jamais après ce récit, il faudra enfin que notre génération renonce à son existence d'emprunt. Vous lui fermez le retour vers ce passé ; il n'est plus possible ; après ce que vous dites" (Le Guillou 549).

For George Sand and Victor Hugo nonetheless, the relationship the French have with their revolutionary heritage is more complex. Nanon 
(published in 1872) and 93 (published in 1874), ponder the tensions existing in society in the nineteenth-century. On the one hand, one wants to side with Quinet and affirm that the revolution is past. On the other hand, how to deny that the events of 1830,1848 and 1871 were fathered by 1789 and 1793 ? The Revolution outlived its actors, who bequeathed to future generations a contentious political scene. My hypothesis is that nineteenth-century society developed in the stretching gap between republican ideals and their delayed realization. Quinet's affirmation is a wish that still had not been granted by the 1870 's. The Commune, therefore, was the product of historical tensions within the ambiguous past since the Revolution, and presented itself as the memory crisis' strongest symptom.

I now propose to show that Sand and Hugo made an attempt to reconcile society with itself after the Commune. To do so, they traced the origin of the rupture within society back to the Revolution, in order to understand the present and to prepare France for modernity. They retrospectively exemplified De Certeau's argument about history, 'la place qu'elle taille au passé est également une manière de faire place à un avenir' (Certeau 100). After assessing the state of France's historical memory in the postCommune era, Sand and Hugo advocated the construction of a better nation, through mythical sacrifices. Indeed, shaping the nation implied coming to terms with History by homogenizing collective memory. The idea was that all classes would be able to refer to the same History, while analyzing their past in order to understand their present. Their irreconcilable takes on what collective memory should be, however, made the task a complex one.

Throughout the nineteenth-century, the societal rupture, with its revolutionary origins, prevented the nation from fully forming. It was a repetition of this failure, which was acted out during the Commune. In her novel Nanon, Sand traces the origin of the 1871 political turmoil back to the Revolution. The life of the eponymous heroine Nanon is almost an allegory for nineteenth-century French history. Indeed, Nanon, who was a teenager in 1789 , decided to write her "mémoires" in 1850 , that is to say two years after the events of February and June 1848. The novel itself was published a year after the fall of the Commune. Through Nanon, who merges in perspective with George Sand, the nineteenth-century becomes aware of itself and of the strain tearing apart French society. Nanon, living during the Revolution, offers to the 1872 reader a vivid illustration of the revolutionary events that may have caused contemporary troubles. It is important to distinguish, in what I have been calling the Revolution, between two antithetical moments. If 1789 symbolizes reconciliation, 1793 incarnates rupture. 'Il faut nous débarrasser des theories de 93' wrote 
Sand, 'elles nous ont perdus. Terreur et Saint-Barthélémy, c'est la meme voie' (Politique I 275). Hugo would certainly agree with her, since the third book of his third chapter in 93 is entitled 'Le massacre de la SaintBarthélémy' (973). Whereas 1789 is the time of the 'Fête de la Fédération' and of reconciliation among the French people toward the shaping of a French nation, Hugo's 93 relates the Vendée wars that took place during the dramatic year of 1793 and emphasizes rupture as a fundamental aspect of the Revolution. The more heads fall, the more estranged to the Ancien régime French society becomes, or so thought the revolutionaries described by Hugo. Thus, of 'La Tourgue' - a feudal castle belonging to Gauvain and Lantenac's family - he wrote: 'Dans la Tourgue étaient condensés quinze cents ans [...]; dans la guillotine une année, 93; et ces douze mois faisaient contre-poids à ces quinze siècles' (1061). The two-act Revolution led to a new society in two periods. Before inaugurating modern history, it inscribed feudality within the realm of the past.

During the Revolution new relationships emerged within society. The revolutionary onslaught on Old Regime hierarchy brought forth changes for the aristocracy, as well as changes of relations between the 'orders' (clergy, nobles and third estate). Therefore, in Nanon, the second-born marquis is no longer pressured to remain in a convent, the Revolution having liberated him from primogeniture. As a consequence of the orders' overthrow, the Marquis de Franqueville may marry Nanon the peasant. Everyone, however, does not accept such changes and Emilien, the Marquis, declares that "l'alliance du noble et du paysan est plus facile que l'alliance de la bourgeoisie et de la noblesse. Ces deux classes se haissent trop" (226). This is why Nanon and Emilien share an idyllic love, while the bourgeois Costejoux and Louise, Emilien's sister, endure a strife-filled relationship. Sand here stresses two points: not only did the nobles never forgive the bourgeoisie for usurping their power; this rancor is still very much alive at the end of the nineteenth-century'. Along with a loss of political supremacy, the nobles have to accept that their memories of past grandeur have become hopelessly anachronistic:

Une intrigue annexe entre Costejoux et Louise, la soeur d'Emilien, permet à George Sand de développer une réflexion sur la séparation que représente encore la mémoire de la noblesse, séparation que le temps devra suturer. (Neefs 140)

What exactly does this memory consist of? In 93, Lantenac, who is imprisoned in the Tourgue, admonishes Gauvain and denounces the Revolution soon to deprive France of its aristocratic memory: 
Monsieur le vicomte, vous ne savez peut-être plus ce que c'est qu'un gentilhomme. Et bien, en voilà un, c'est moi. Regardez ça. C'est curieux : ça croit en Dieu, ça croit à la tradition, ça croit à la famille, ça croit à ses aïeux, ça croit à l'exemple de son père, à la fidélité, à la loyauté, au devoir envers son prince, au respect des vieilles lois, à la vertu, à la justice [...]. (1044)

Lantenac in 93 and Louise in Nanon are the most attached to the nobility's memory and traditions. After the end of the Terror, Louise leaves Costejoux. To Emilien, who asked where and with whom his sister had gone, Costejoux answered:

Avec sa vieille parente, Mme de Montifault, la Vendéenne, la chouanne irréconciliable! Chargée par vos parents de veiller sur Louise, mais empêchée longtemps par le louable devoir de fomenter et de continuer la guerre civile, elle a pu enfin sortir du repaire ; elle est venue hier soir chercher Louise, et Louise l'a suivie. -Sans résistance? -Et sans regret ! (228)

The brother, Emilien, however, did not remain attached to memory associated with his class. To the example of his father, who fled France and joined the other Emigrants, Emilien opposed his own will and determination: "je ne suis le fils de personne quand il s'agit de trahir la France" $(105){ }^{2}$ When a noble thinks about marrying outside her class, it is not only the class of the spouse that will determine if the alliance will survive. It is first and foremost the noble's memory of his own nobility. Emilien, having renounced the aristocracy's traditions, easily marries Nanon, but it is only once Louise has detached herself from the memory of nobility that she loses her prejudices toward other classes, and consents to marry Costejoux.

As described above, nobles share a collective memory, but this memory is closely connected to feudalism. Not only is there a set of rules to determine the nobles' behavior within their class; in addition, nobles could foist their will on the people. Originally, feudalism was a system in which the poor paid taxes to the rich, in exchange for physical and material protection in time of war. In the eighteenth-century, taxes were still due to the aristocracy, although the duty to fight did not exclusively devolve upon its members anymore. The authentic feudal link between vassal and overlord had been broken for a long time before the Revolution, and what the Revolution attempted to end is the corrupt and unequal version of feudalism. Many aristocrats, however, acted during the Revolution as if the ancient feudality were still governing society. Thus in Nanon, Emilien's father joined the Emigrants because he believed his sword had to 
defend the monarchy: "Fournissez à M. Emilien l'argent nécessaire pour sortir de France et venir me rejoinder à l'armée de Condé," writes M. de Franqueville to Prémel, one of his servants. His action is justified by the ancient rules governing feudalism. Like Lantenac, the Marquis believes in serving the Prince.

In 93, Lantenac also acts and talks as if the ancient mechanism of feudality was still operating:

Ah! Vous ne voulez plus avoir de nobles! Eh bien, vous n'en aurez plus. Faites-en votre deuil. [...] Vous n'aurez plus les chevaliers de Fontenoy qui saluaient avant de tuer [...] si Alaric II revient, il ne trouvera plus en face de lui Clovis; si Abdérame revient, il ne trouvera plus en face de lui Charles Martel ; si les Saxons reviennent, ils ne trouveront plus devant eux Pépin. (1046)

Lantenac even refers to early feudalism, and to the legends that formed the memory of the aristocracy. In 93, there is an allusion to what feudality used to be in the Middle Ages, through the name of the hero, Gauvain. The name "Gauvain" takes us back to Chretien de Troyes and the age of medieval chivalry. Indeed, Gauvain clings to honor, the knight's dearest virtue. "Vainqueur, il se croyait le droit d'épargner les vaincus" (949), and, if really he needs to condemn his enemy to death: "Moi, dit Gauvain, je suis pour la mort militaire" (950), which he opposes to revolutionary death by the guillotine. Gauvain never gives up on "honor," and while he is being tried, he defends himself with these words: "Je suis coupable. [...] Quand le coupable reconnait sa faute, il sauve la seule chose qui vaille la peine d'être sauvée, l'honneur" (1051). Since medieval times, feudalism declined, and reversed itself in 93, where aristocratic values are now cherished by those who defected from its rank ${ }^{3}$. Honor is on Gauvain's side, not on Lantenac's, who eventually admitted to his nephew: "Je ne vous cache pas que j'ai fait ce que $\mathrm{j}$ ' ai pu pour vous tuer. Tel que vous me voyez, j'ai trois fois, moi-même, en personne, pointé un canon sur vous. Procédé discourtois, je l'avoue" (1044). ${ }^{4}$

The transfer of the aristocratic value, "honor," from the marquis de Lantenac to the Vicomte Gauvain is significant, and brings us back to the Middle Ages and to the chevaliers de la table ronde, where Gauvain was King Arthur's nephew. In Hugo's 93 however, Lantenac is no King Arthur. The corrupted version of feudalism at the end of eighteenthcentury France bars any such analogy. Moreover, after January 21, 1793, the King was dead.

Although the king was beheaded, time has not yet come for "la république de l'idéal" (93 1056), an expression Gauvain coined. "La république 
de l'idéal" is where Gauvain and Nanon meet. In a 1871 letter addressed to Juliette Adam, Sand wrote that "la République de l'idéal est loin, loin dans l'avenir" (Politique I 262). The 1792 Republic failed, as did the Commune, which Sand qualified as a "crise de vomissements" (Politique I 261). It is the Commune, the historical experience of a failure in reconciling the French with themselves, which prompted Sand and Hugo to search for the origin of this failure. Both perceived it in the French Revolution, which embodied a better idea of the future through reconciliation in 1789 , and which betrayed it in 1793 because of corruption (in Nanon, the bad monk Pamphile becomes a revolutionary who kills in his own interest) and because of human weakness: good-hearted people like Gauvain are too soft, and loyal revolutionaries like Cimourdain choose death over survival in a Revolution who guillotines her own children.

The fall of reconciliation into rupture, between 1789 and 1793, accounts for a remark by Michelet stating that the 1789 Revolution was a rupture and a foundation too. "Il ne faut pas dire: la Révolution, mais la Fondation" (Cours au collège de France (CCF) $2: 10,19$ ). The concepts of religion, family and country are wholly experienced after the Revolution, and this is mostly because of 1789 , not 1793 . And I will add, too, since Michelet was a historian, that in his view: "la troisième chose qui nous est devenue possible par la Révolution, c'est l'histoire" (CCF 2: 691). In his 1865 book La Révolution, Edgar Quinet endorsed his former colleague's view. ${ }^{6}$ The founding of a nation is what makes its history possible. Thus the concept of modern history was born.

The tension between reconciliation and rupture left a scar in French consciousness, and this scar allowed modern French history to unfold. Sand and Hugo witnessed its beginnings. "En un sens," wrote Béatrice Didier, "tous les romans de George Sand sont 'historiques' dans la mesure où la présence de l'Histoire y est fortement sentie, fortement rappelée" (752). Nanon takes place from 1787 to 1850 , and even though no real historical character appears in the novel, events such as the Fête de la Fédération or the creation of the Comité de Salut public reproduce the historical setting of the revolutionary period. The real Vendée uprising that took place in 1793 and its leaders, such as Cathelineau and Bonchamp, constitute 93's historical background. The difference between Nanon and 93, as far as History is concerned, is that Marat, Danton and Robespierre not only are mentioned in 93 , but also actually engage in fictitious dialogue.

The advantage of a novel based on a historical background is of consequence. Sand and Hugo use History in order to demonstrate what the French Revolution implied for the nineteenth-century, and conversely, their 
ideas are justified by History itself. As Hugo wrote to Michelet in 1866, "[J]e ne suis rien que le témoin du dix-neuvième siècle' (Correspondance générale 10:67). He and Sand gave this century a subjective voice, which is not that of Marat, but that of a people talking behind Marat, or Nanon. Hugo and Sand's respective interpretations of revolutionary dialogue reveal their sense of History. The foundation of history started in a very tense society where feudality, a system that had regulated French society since the Middle Ages, was falling to pieces. Subsequently, new values emerged to replace the ones cherished by the Old Regime. During the Revolution, the French sought to revise the values attached to family, country and religion.

In his Cours au collège de France, Michelet advocated family and country as new values for the French people (2: 143). Family and country start with fraternity. "Il faut, pour que le monde nous vienne [...] qu'il nous voie un cœur fraternel. C'est la fraternité de l'amour qui le gagnera, et non celle de la guillotine" (Histoire de la Révolution française (HRF) 4). Externally, fraternity explains why the Revolution "avait convié le monde à l'amour et à la paix [...]" (HRF 2). Internally, it calls for stronger family values.

Nanon is predisposed to family values from the start. While she is crying over the death of her great-uncle, who raised her after the death of her parents, Emilien tells her, "[T]u as une grande force d'amitié; on ne te rendra pas cela comme tu le mérites" (62). Nanon's family during the Revolution is inexistent and broad at the same time. On the one hand it is inexistent because her great uncle was her last relative, but on the other hand it is large because once alone, Nanon idealistically treats everyone in her community as if they were kin to her. For Emilien as well as for her friend Costejoux, Nanon readily sacrifices herself. In Nanon the idea of "family" joins that of a "country" or even "nation." Without openly professing it, she adheres to Michelet's idea, that fraternity is necessary in the building of post-revolutionary French society. In contrast to Nanon, Louise remains cloistered within the Franqueville society, which to her represents family in terms of class. Through her last name, Louise seeks to reclaim her aristocratic origins. While she pines for the Old Regime, Nanon celebrates a new family, which embodies the ideal of republican fraternity.

In 93, family is represented by Michelle Fléchard and her children. This however, is more about maternity than about family, since it is the mother's frightening scream that saves her children in the end. Eventually, Sand and Hugo conceptualized the progression from "family by 
blood" to "the nation as a family." In this progression, Sand nonetheless saw one movement where Hugo distinguished two. If Sand thought that post-revolutionary society envisioned family values as progress towards fraternity within the nation, Hugo speculated that progress towards fraternity via family values first required a step back, towards nuclear family and maternal instinct. Michelle Fléchard and her children embody this first step. Secondly, it is only after maternity was affirmed as a basis for modern society, that Hugo in 93 integrated the idea of the nation as an enlarged family. This second moment is embodied by the adoption of Michelle Fléchard and her children by the Sergeant Radoub and the Bataillon du Bonnet Rouge: "Camarades, de tout ca je conclus que le bataillon va devenir père. Est-ce bien convenu? Nous adoptons ces trois enfants là. —Vive la République! Crièrent les grenadiers" (797). Therefore, while Nanon imbricates family values and post-revolutionary society, 93 advocates family "in a state of Nature," in which the single mother raises her children and obeys her instincts, which can be compared to those of a wolf: "La mère reconnut ses enfants. Elle jeta un cri effrayant. Ce cri de l'inexprimable angoisse n'est donné qu'aux mères [...]. Quand une femme le jette, on croit entendre une louve ; quand une louve le pousse, on croit entendre une femme" (1023).

The progression in Hugo from nuclear family to the nation-family requires the sacrifice of feudality: "abolir la féodalité, c'est fonder la famille" says Gauvain (1037). Gauvain's death reinforces the idea that though feudal values (and especially the honor that Gauvain embodies) may vanish, feudality as a system never will. In setting Lantenac loose, Gauvain accepts that the dominant class is stronger and should win, which violently contradicts the idea of a nation as an enlarged family, and restores the reign of Nature. Family relationships in 93 show that the Revolution will not change people's minds', because society holds on to its most traditional and natural values, even in the midst of violent upheaval. Gauvain, like Nanon's uncle, the père Jean, dies before any significant social change can occur. With Gauvain's death, Hugo stresses the Revolution's failure to penetrate the French mind.

Michelet wrote, "Il ne faut pas que la Révolution soit extérieure [...] il faut qu'elle entre et pénètre" ( $C C F$ 2: 393). ${ }^{7}$ Later Quinet subscribed to this view: "La révolution doit transformer l'homme en dedans. Sinon, elle n'est pas terminée" (144). The Revolution, however, tried to permeate French society through the concept of country, or nation. The Fête de la Fédération, on July 14, 1790, served this purpose.

In 1848, "le gouvernement provisoire a convié le peuple au Champ de Mars pour y célébrer la fete philosophique de l'oubli des haines et y 
bruler l'échafaud" (Blanc V). George Sand was there, on April 21, 1848 (Schor 135). This is, I am assuming, what prompted Sand to accord such importance to the Fête de la Fédération in Nanon, in 1850 and 1874. The 14 July 1790 Fête de la Fédération was the culminating point of reconciliation after 1789 , even though a difficult future loomed. Nanon observes after the Fête de la Fédération that "[t]out allait s'embrouiller et se gater" (74). Quinet wrote about the Fête's preparation: "Voilà le moment où les cœurs fraternisèrent véritablement. Le lendemain, 14 juillet, la fete parut froide et officielle [...] le faux entrait de toutes parts [...] les drapeaux [...] les acclamations couvrirent ces presages" $(231) .{ }^{8}$ The gesture nonetheless proves that the French honestly wanted a better nation.

The concept of nation is indistinguishable from that of country. In 1789 , parallel to the idea of a "nation" as an enlarged family, persists that of a nation as a group of people belonging to the same patrie. Before and during the Revolution, the patrie was nothing comparable to what it is today, with each province using its version of the French language, baking its own bread, or weaving its own garments. Patrie is the name of something yet inexistent, just as the pater, or biological "father," is absent from the family in Nanon and 93. The shaping of the French nation via complex family values and via patrie-building implies the restitution the pater figure.

During the Revolution, Paris and the Provinces did not experience the same events. Hugo in 93 separated the actions taking place in Vendée from the ones taking place in Paris. The first and third parts ('en mer' and 'en Vendée') are set in the West, whereas the middle part takes place in Paris and is called "A Paris." In 93 and in Nanon, set in Nohant, Paris is removed from the scene of events, although in both novels characters implicitly acknowledge that Paris is the "avant-garde" of the Revolution. Decisions and events taking place in the French capital are belatedly echoed in the Provinces.

La revolution était donc commencée et nous ne le savions pas. Pourtant le bruit de la prise de la Bastille se répandit un jour de marché, et comme cela causait quelque émotion dans la paroisse, je fus envieuse de savoir ce que cela pouvait être : la Bastille! (Nanon 49)

This delay between the time events took place, and the time peasants in Nohant became aware of them, changed the peasants' perception, compared to how Parisians could perceive the same event. Thus, although the fall of the Bastille was in Paris more important than the "grande peur" that followed it, Nohant's inhabitants took the opposite view: "Le souvenir. 
de cette panique est resté dans nos campagnes comme ce qui a le plus marqué pour nous dans la revolution. On l'appelle encore l'année de la grand-peur" (52). The fact that the Provinces were marked by the "grandpeur," which started through rumors, and less by the fall of the Bastille, reveals a gap between the educated Parisians and the illiterate peasants. Hugo, aware of this gap, weighed almost literally the Revolution and the peasant from the Province:

Si l'on veut comprendre la Vendée, qu'on se figure cet antagonisme: d'un coté la revolution francaise, de l'autre le paysan breton. En face de ces événements incomparables [...] qu'on place ce sauvage grave et singulier [...] vivant de lait et de chataignes $[. .$.$] ayant sur le dos une veste de cuir avec des$ arabesques de soie, inculte et brodé, tatouant ses habits comme ses ancetres les Celtes avaient tatoué leurs visages [...] parlant une langue morte [...] aimant ses rois, ses seigneurs, ses pretres, ses poux [...]. Et qu'on se demande si cet aveugle pouvait accepter cette clarté. (916)

The Revolution fought for the patrie, when peasants from Brittany fought for the local "pays." Later on Hugo very clearly explained what was "civil" in the war among the French, between the Vendée and the Revolution: "Pays, Patrie, ces deux mots résument toute la guerre de Vendée; querelle de l'idée locale contre l'idée universelle; paysans contre patriots" (925). ${ }^{9}$ Moreover, only the revolutionaries were able to conceptualize the patrie: "L'idée vivante de patrie n'existait que parmi les révolutionnaires. L'ancien régime ne voyant la France que dans le roi, livrait sans remord une patrie qu'il ne reconnaissait plus" (Quinet 407). Therefore forming a nation also requires the sacrifice of one's "pays." The local "pays" must disappear in order for the patrie to exist. This is what Nanon expresses at the end of Nanon: "Devant le grand dévouement de mon fiancé à la patrie, j'étais devenue moins paysanne, c'est-à-dire plus Française" (234). Nanon relinquished her local identification to a "pays" in order to shape her French identity and become part of the French nation. ${ }^{10}$

Very closely tied to the discussion of patrie and "pays" is that of religion. The Fête de la Fédération, along with being a first step toward nation building, inaugurated a series of fraternal 'fêtes' which all resembled each other. Thus, the Fete de la Federation in Nanon prefigures the religiously inflected Fête de la Raison.

Nanon, dressed as a kind of a Greek goddess on July 14, 1790, recalls the debate between traditional Catholicism and alternative deism. Despite 
her Greek outfit, Nanon is far from being a pagan and recites her prayers every night. The revolutionary characters in Nanon (Costejoux) and in 93 (Gauvain, Cimourdain) do not plea for the abolition of religion and, so, differ from actual revolutionary discourse. This we may perhaps attribute to historical distance; although Sand and Hugo set their novels during the Revolution, they wrote them in the early eighteen seventies.

Patrie and religion go together. "La patrie," wrote Michelet about education, "doit aider à ce mouvement vers le haut. Elle doit avoir un role de prévoyance maternelle" (CCF 2: 30). The patrie performs the roles of father, mother, and Providence : "Enseignez d'abord [...] la patrie, comme Verbe de Dieu" (CCF 2: 93). Michelet and Quinet disagreed about what place Christianity played after the Revolution. For Michelet, the Revolution opened society to the possibility of a new religion, because in the Revolution itself he saw a new Church. He wrote in the 1868 preface to the Histoire de la révolution française: "Elle [la Révolution] n'adopta aucune Eglise. Pourquoi ? C'est qu'elle était une Eglise elle- meme" (HRF 12). For Quinet, however, the Revolution did more for Christianity than for the nation:

Le sang des Cathelineau [...] les paysans de Vendée ont obtenu ce qui leur mit les armes à la main. Ils ont gagné pour leur postérité la suprématie, en fait, de leur religion, la domination réelle de leurs prêtres, de leurs autels; ils les ont rétablis, non seulement pour eux, mais pour toute la France. Au contraire, la religion de liberté de leurs adversaires [...] Elle a disparu des âmes plus encore que des choses. (412)

This suggests that in 93, the victory of Lantenac is really that of Catholicism, especially in 1874. Indeed, the Vendée lost, but not Catholicism, celebrated in Le génie du christianisme no later than ten years after the fall of Louis XVI. Hugo shed light on the major fact that rather than abolish Catholicism, the Revolution made it appear in a state of crisis, from which issued its regeneration.

On a milder note, Sand did not portray Catholicism in a state of crisis. To her, the Revolution actually improved relations between the Clergy and the people. Nanon after all, persuades to the Père Fructueux, the new head monk in the Moutiers, to become "assermenté," or to swear to be loyal to the new Constitution. Therefore, the new Church of the Revolution results from the convergence of Catholicism and the Enlightenment.

As with family and the patrie, the celebration of religion requires a sacrifice. The eponymous heroine of Nanon offers herself as a sacrifice to 
the better times to come. She jeopardizes her own life for that of Emilien, sacrifices her beloved lamb Rosette for the well-being of Louise, and on the whole acts by gestures of abnegation, which eventually are rewarded. In 93, religion exacts a heavier toll: with his death, Gauvain expiates the crimes of Lantenac. It is afterwards an absolved Lantenac who departs from the Tourgue, not only to carry on the war against the Revolution, but also to defend the Vendée and uphold its Catholic traditions.

In the early Third Republic, Sand and Hugo managed to synthesize what the French ideologically inherited from the Revolution. After the fall of the Commune, time had come for the French to ponder how, practically, to assimilate this heritage - or, as Hugo put it, how to begin the "révolution humaine." For Sand's funeral, he wrote, "Dans ce siècle qui a pour loi d'achever la Révolution française et de commencer la révolution humaine [...]. Je pleure une morte et je salue une immortelle" (Bahiaoui 9-10). The human revolution, however, is just a part of a bigger scheme. It is time to prompt French society towards scientific and capitalist modernity in spite of itself. After the Franco-Prussian war, France understood it was being forced into modernity. Accentuating factors of reconciliation internal to society, such as family, patrie, and religion, was part of a double movement: moving backwards toward the Revolution, in order for the nation to assimilate it and understand its sacrifices at the time and entering modernity with more strength and unity. In Nanon and in 93 there is hope that the Commune was the last repetition of the sacrificial rituals necessary to shape the French nation. "Quant à la Commune, qui est en train de raler, c'est la dernière manifestation du Moyen-Age," wrote Flaubert to Sand in April 1871. "La dernière? Espérons-le !" (Correspondance Sand-Flaubert 332). The beheading of Gauvain in 93 also marks the burial of the Arthurian patronym. In Nanon, the link between the Revolution and the MiddleAges is broken through Emilien and Louise's loss of aristocratic memory.

Sand hoped to witness, in the post-Commune era, a resurgence of that sense of nationhood, whose promise had flickered briefly on July 14 , 1790. The reconciliation that followed the Commune retrospectively ended and sealed the Revolution's aborted attempt to constitute a nation and a "patrie." For Sand, family sustains the patrie's "epanouissement," for in defying the traditional conception of the nuclear family, she promotes a family as large as the nation. She is therefore close to Michelet, who in 1850 declared, "Notre foyer éphémère participe pourtant à l'éternité du foyer de la patrie" (CCF 2: 623).

Like family and the patrie, religion is in Sand's view a unifying and a strengthening force. She nonetheless departed from traditional Christian- 
ity, advocating instead an enlightened religion which still bore traces of the Revolution. "Que doit faire l'homme," wrote Michelet, "Une chose qui en comprend trois : famille, religion, patrie" (CCF 2 : 580). Nanon learned the new religion through her numerous sacrifices, and we can affirm more generally that the sacrifices required by the Revolution helped shape a certain idea of God. "J'ai enseigné que la Révolution n'était rien," wrote again Michelet, "si elle ne prenait racine dans le sacrifice et que le sacrifice n'était ni facile ni général autrement que par la foi et par la pensée de Dieu" (CCF 2: 645-646). In 1850, it is Nanon, Michelet's fictitious contemporary, who seems to agree with the historian. Sand used Nanon to reinforce Michelet's mid nineteenth-century historical discourse on the Revolution. She thus preserved, in the on-going project of nationhood, the nexus of society and religion.

On the other hand, Lantenac is antithetical to Nanon. Hugo's opinion of the Revolution and its legacy tends to contradict Sand's optimism. Where Sand observed progress and reconciliation, Hugo saw regression towards the Old Regime value system. Nanon could save Louise from the guillotine in spite of the aristocrat's opposition to the Revolution because in Nanon the enlarged family trumps violence and rupture. In 93, however, Gauvain signs his own death warrant in forgiving his Vendean uncle. In setting Lantenac free, Gauvain subsequently adheres to his uncle's aristocratic notions attached to family. In the aristocratic family, the father does not establish harmony, but embodies authority. To the enlarged nation-family, Lantenac opposes an enlarged conception of the father, who is not so much a biological father, as a chief. The Marquis decides after all, whether or not the Fléchard children will live; he does not eventually save them out of pure altruism - after all, it was he who locked them in La Tourgue in the first place - but to assert his absolute commanding position. Had the mother tried to jeopardize his authority and argued with him, he would probably not have saved the children. The wolf-like scream, however, propels the Marquis back inside La Tourgue to rescue the children from the flames. To Sand's utopia, Hugo opposes a world still based on instinctive patriarchal authority. In 93 the nation's values are subsumed under that of the Vendée, whose traditions and religion resurface strengthened. The "pays" and its Catholic traditions are eventually victorious, thus proving Quinet right.

Whereas Sand confirms Michelet's thesis and advocates enlarged family as the basis of the new nation, Hugo, through Lantenac, uses Quinet's conclusion in order to profess religion as the nation's cornerstone. Each opposes the other, as idealism opposes fatalistic realism; but if until 
the early twentieth-century religion remained important to French society, social reforms, responding to the idea of enlarged family, kept developing throughout the third Republic and the twentieth-century. Sand and Hugo initiated progress towards reconciliation, which eventually developed through the patrie's institutions.

\section{Notes}

1. Moreover, the Terror was led by the bourgeoisie, as the involvement of Costejoux in the Revolution illustrates. Michelet wrote: "les meneurs, nos grands Terroristes, n'étaient nullement des hommes du peuple, mais des bourgeois, des nobles, des esprits cultivés, subtils, bizarres, des sophistes et des scolastiques. » Le peuple (Paris : Flammarion, 1974) 135.

2. With this act, "le personage d'Emilien représente en actes la rupture avec l'ancien monde, en déclarant la rupture avec sa famille". Jaques Neefs, "Nanon, une fable de la mémoire historique." In George Sand: Littérature et politique (Nantes : Pleins feux, 2007) 139.

3. Emilien, defecting its rank by deciding to not join his father in Gernany, recalls the notion of honor too, when revolutionary war is mentioned : « Je suis né doux et je n'ai pas le gout de tuer des hommes ; mais il y aura peut-etre une question d'honneur et tu ne voudrais pas me voir méprisé ? » Nanon 94.

4. "Subitement, un éclair jaillit [...] et un boulet vint trouer une maison au-dessus de la tête de Gauvain. [...] Un second boulet suivit le premier et vint s'enfoncer dans le mut tout près de Gauvain. Un troisième boulet jeta à terre son chapeau. [...] Quelqu'un en effet visait Gauvain, c'était Lantenac. » (937-938)

5. "On oubliera pas, en premier lieu, que les écrivains contemporains, si l'on met à part Victor Hugo nuancé, Rimbaud et Verlaine qui n'ont rien écrit de très substantiel sur le sujet, Jules Vallès qui, lui, prit une part directe à l'événement, ont à peu près tous été violemment hostiles au mouvement parisien. La Commune a généralement été ressentie comme une apocalypse sociale, expression en pleine civilisation des pulsions les plus primitives et les plus bestiales de l'homme. » Littérature et histoire, George Sand: histoire et terroir (Rennes : Presses Universitaires de Rennes, 2006) 267. It is interesting to notice that bestiality, appearing in Michelle Fléchard's scream in 93, is what propulsed the last events of the novel, that is to say Lantenac's arrestation and Gauvain's beheading.

6. « Dans la France de l'ancien régime, écrire l'histoire de France était impossible. Cette histoire, avant la Révolution, n'avait été traitée 
par aucun grand esprit. Apparemment, le récit de cette longue servitude semblait intolérable ou indigne d'intérêt. [...] Il en fut autrement lorsque la liberté eut commencé à paraître. 》 La Révolution 67.

7. and later, in a letter to Quinet « Vous l'avez dit, c'est dans les esprits mêmes qu'il faut faire la révolution. Mais en meme temps, elle se fera profonde dans les choses. » 25 sept.53. In Correspondance générale de Michelet vol. 7, 561.

8. Mme de Stael herself wrote "Les spectateurs étoient dans l'ivresse ; le roi et la liberté leur paroissoient alors complètement réunis [...] Toutefois les personnes capables de réflexion étoient loin de se livrer à la joie générale » Considérations sur la Révolution francaise, ed. Jacques Godechot (1818; Paris : Tallandier, 1881, 1983) 227.

9. The dialogue between Radoub and Michelle Fléchard in the beginning of the novel also established a distinction between « pays » and «patrie »: «Quelle est ta patrie ? -Je ne sais pas, dit-elle. -Comment, tu ne sais pas quell est ton pays? -Ah! mon pays, si fait. » (792)

10. See also George Sand, Terroir et histoire.

\section{Works Cited}

Bahiaoui, Danielle. Correspondance croisée: George Sand Victor Hugo. Nïmes : HB, 2004.

Blanc, Louis. Histoire de la révolution de 1848. Paris: A. Lacroix, Verboeckhoven et ce, 1870.

Certeau, Michel de. L'écriture de l'histoire. Paris : Gallimard, 1975.

Didier, Béatrice. George Sand écrivain : un grand fleuve d'Amérique».

Paris: Presses universitaires de France, 1998.

Flaubert, Gustave, George Sand, éd Alphonse Jacobs. Correspondance.

Paris: Flammarion, 1981.

Hugo, Victor, éd Jacques Seebacher. Oeuvres complètes. Paris: R. Laffont, 1985.

Le Guillou, Louis, ed. Correspondance générale de Michelet. Vol. 7. Paris : Honoré Champion, 2000

Michelet, Jules. Cours au Collège de France, 1838-1851. Paris: Gallimard, 1995.

. Correspondance générale. Paris: Librairie Honoré Champion, 1994. - Le peuple. Ed. Paul Viallaneix. Paris: Flammarion, 1974.

- Histoire de la Révolution française. Ed. Gérard Walter. Paris: Gallimard, 1961. 
Neefs, Jacques. « Nanon, une fable de la mémoire historique » éd. Martine Reid et Michèle Riot-Sarcey. George Sand :littérature et politique. Nantes: Pleins feux, 2007.

Quinet, Edgar. La Révolution. Paris: Belin, 1987.

Sand, George, éd Huguette Bouchardeau. Politique. Nîmes: HB éditions, 2004.

Sand, George, éd Nicole Mozet. Nanon. Meylan France: Editions de l'Aurore, 1987.

Schor, Naomi. George Sand and Idealism. New York: Columbia University Press, 1993.

Staël, Mme de. Considérations sur la Révolution française. Ed. Jacques Léon Godechot. Paris: Tallandier, 1983.

Terdiman, Richard. Present Past: Modernity and the Memory Crisis. Ithaca, N.Y.: Cornell University Press, 1993.

"Littérature et histoire." George Sand, terroir et histoire. Dir.Noëlle

Dauphin. Rennes: Presses universitaires de Rennes, 2006. 